\title{
The Singapore English Press in The 1970s
}

\author{
Lingyi Huang \\ College of Foreign Languages and Cultures \\ Xiamen University \\ Xiamen, China \\ ilovexmu2015@126.com
}

Keywords: English Press; Singapore; Media; newspaper; 1970s

\begin{abstract}
The English Press in Singapore has unique features in a country that functions under Authoritarian System. In the 1970s, the whole press (both English and Chinese) faced challenges and pressure from the control of the government. Tightening measures and laws were implemented, therefore the English press had to readjust the orientation and tried to cater to the need of nationbuilding and fostering of the spirit of being Singaporeans. The period in the 1970s was the time that both sides had the fiercest conflicts and the key stage the government began to lay down the complete and effective supervision system. A careful and thorough analysis into the English press at that time helps to reveal a more profound picture of that special phrase and paves the way to a deeper understanding between power and media.
\end{abstract}

\section{Introduction}

In a multicultural and multi-lingual society, Singapore English press has its unique features in the development in a post-colonial age.

In 1965, Singapore gain independence and founded the republic, proclaiming the opening of a new age, with the People's Action Party dominating the government. The new government faced challenges not only in national economy after a long colonial age, but a defiant press circle that pursued the "Fourth Estate" concept which is popular in western press.

How to effectively control the press, especially the English press and how English press reacted to a series of tightening measure from the government? The English press had presumed what kind of role after several rounds of fight and concession? These are all the important questions I would like to find out in the following analysis.

\section{The Singapore English Press in the 1970s}

After the autonomy in 1959, at that beginning of developing a new nation, difficulties piled up in every aspect. In 1960, the unemployed workers reached 45,000, and $25 \%$ of the population lived under the poverty line.[1] Due to the poor economic state, literate people accounted for only $52.3 \%$ of the whole population, with ethnic Chinses representing 46.2\%, Indian 75.2\% and Malay 62.2\%.[2]

Effective economic policies were issued by the People's Action Party, and Singapore's economy witnessed fast growth after 1968. Thanks to a series of effective measures, the large input in the educational system also began to yield positive outcomes. As can be seen in Fig. 1 below, The Literate Rate in Singapore rose from only 52.3\% in 1957 before independence, to $84 \%$ after the 1970 s. 


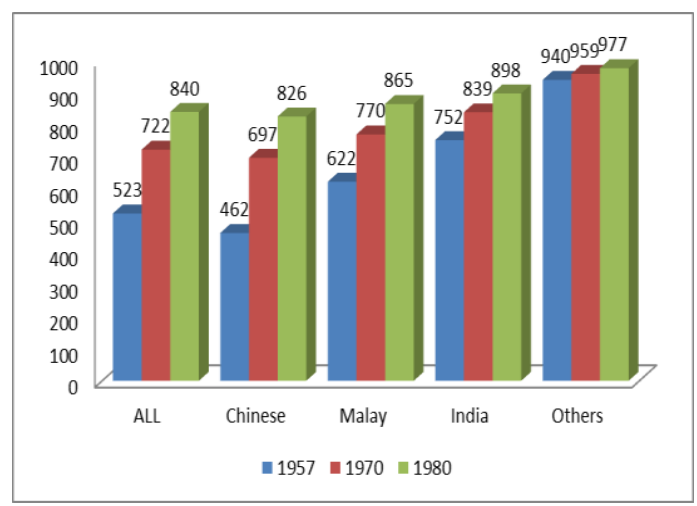

Figure 1. The Literate Rate in Singapore in 1957, 1970 and 1980(, 000), (See Saw Swee-Hock, 2007, p47).

Since Singapore is a multilingual society, the number of people with bilingual ability also rose quickly, due to the implementation of the language policy in the 1960s. English, Chinese, Malay, Indian are the four official languages of the country, with English as the de facto dominate working language. Moreover, the government had enforced "Bilingual Education Policy" in schools, giving English dominant role in the system. Therefore, the English-speaking group was expanding at an ever-increasing rate. People knowing English accounted for $46.7 \%$ in 1970, and 55\% to 1980, and $64.1 \%$ in 1990 . And the bilingual population rose from $19.1 \%$ in 1970 to $37.5 \%$ in 1980 .

All these factors pushed forward the fast growth of the press. By the beginning of 1971, Singapore has 4 English newspapers: the Straits Times, the Singapore Herald, the New Nation, and the Eastern Sun.

In 1974 Singapore had 11 daily newspapers, of which 3 are English, 4 in Chinese. The total Daily newspaper circulation in 1976 was about 477,000, and went up to 527,000 in 1977 with 15 newspaper published daily. Four are Chinese newspapers (total circulation of about 246,500), while three are in English (total circulation 315,000). And the largest English newspaper in Singapore is Straits Times, with a circulation of 180,723 in 1980.

Table 1 Circulation and readership of Singapore English newspapers in 1976/1977/1980

\begin{tabular}{|l|l|l|}
\hline Newspaper & Circulation (1970) & Circulation (1976/1977) \\
\hline Straits Times & 111,798 & 151,342 \\
Sunday Times & & 161,784 \\
New Nation & 20,000 & 39,565 \\
Sunday Nation & & 55,270 \\
Business Times & & 4,500 \\
\hline Newspaper & Circulation & Circulation \\
& $1978 / 1979$ & $(1980 / 1981)$ \\
\hline Straits Times & 180,723 & 180,000 \\
Sunday Times & 189,024 & 200,000 \\
New Nation & 45,099 & \\
Sunday Nation & 87,020 & \\
Business Times & 5,000 & 5,000 \\
\hline
\end{tabular}

Source: For number in 1970, see Chen, Peter C.J. \& Kuo, Eddie C.Y. Mass Media and Communication Pattern in Singapore, and Singapore: AMIC, 1978, P 53; Media Directory: Singapore, Malaysia and Brunei, 1976/1977; Kuo, Eddie C.Y., Communication Policy and Planning in Singapore, London: Kegan Paul International: 1983,P26; Media Directory: Singapore, Malaysia and Brunei, 1978/1979;

Malaysia and Brunei, 1980/1981. Media Directory: Singapore,

And from the circulation number between the Chinse and English press( see table 2), we can clearly figure out that although both newspapers were gaining more readership and expanding 
circulation, English press were growing at a much faster speed and the gap between the two kinds of press were narrowing gradually.

Table 2 The Contrast Between Circulation Numbers of Chinese Newspaper and English Newspapers

\begin{tabular}{|l|l|l|}
\hline & Circulation & Per thousand \\
\hline Chinese newspaper & \multicolumn{2}{|l|}{} \\
\hline 1974 & 223,300 & 100.6 \\
\hline 1975 & 227,400 & 101.1 \\
\hline 1976 & 235,200 & 103.2 \\
\hline 1977 & 245,900 & 106.5 \\
\hline English newspaper & \multicolumn{2}{|l|}{} \\
\hline 1974 & 161,479 & 73.9 \\
\hline 1975 & 168,000 & 75.7 \\
\hline 1976 & 206,000 & 90.4 \\
\hline 1977 & 215,000 & 93.1 \\
\hline Total & & \multicolumn{2}{|l|}{} \\
\hline 1974 & 422,500 & 190.4 \\
\hline 1975 & 448,000 & 199.1 \\
\hline 1976 & 477,000 & 209.4 \\
\hline 1977 & 496,500 & 215.0 \\
\hline
\end{tabular}

In order to strengthen the control of media circle, the government began to take actions against Chinese and English newspapers. The two English newspapers Eastern Sun and Singapore Herald got closed down in 1971. And at the same time, the government set up a new English paper Business Times in 1976, for "Straits Times' monopoly frustrate[ed] the Government-it is unable to use the threat of closure effectively since [...] the daily Straits Times fills a commercial need". [3]

Although in the 1970s, the Chinese newspaper did make up an important proportion of the whole press circulation, we can tell from statistics that English media had acquired an increasingly larger readership and since the new readers were mainly young people who were educated under the bilingual educational system, the English newspapers were doomed to play a more decisive role in shaping public opinions.

Kuo argues that because the Straits Times caters to a "cross-ethnic readership, and is relatively freer from ethnic bondage", it will give a more balanced accounts of events and issues that concerns more ethnic communities in Singapore. [4] That's the key reason why we should focus more on English press when we want to incorporate press into the understanding of the history of this country.

\section{Politics and Media}

When taking about media freedom in Asia, Singapore media is often cited as a poor example. "Reports without Borders put the Republic 140th out of 167 counties surveyed for press freedom". So if we want to analyze the its leading newspapers, we must refer to the political, cultural, and social context it functions in.

For Gramsci, societies maintained their stability through a combination of "domination," or force, and "hegemony," defined as consent to "intellectual and moral leadership"; while "media induce consent to the dominant order through establishing the hegemony, or ideological dominance, of a distinctive type of social order". [5]

The relationship between the PAP party and the press during the 1960s and 1970s was full of "tension, suspicion and the lack of mutual trust" [6]. Lee Kuan Yew perceived the Western model of the media as the "Fourth Estate" unsuitable for Singapore. In June 1971, in a speech to the general assembly of the International Press Institute at Helsinki, he asserted, 
"The Singapore Government has the responsibility to neutralize the attempts of foreign agencies and communists to make political gains by shaping opinions and attitudes of Singaporeans. In such a situation, freedom of the press, freedom of news media must be subordinated to the over-riding needs of the integrity of Singapore and to the primacy of purpose of an elected government." [7]

Even Straits Times had a hard time dealing with the former Prime Minister. Lee Kuan Yew had always been "openly dismissive of journalists in general and Straits Times in particular".[8] Even on 20th December 1976, in an election campaign, Lee openly warned:

"If you read, and you understand only the English language, then you are at a very grave disadvantage because you really don't know what is going on in a large part of Singapore. If you believe that the Straits Times and the New Nation is what Singapore is about, you're you are living in a dream world."'[9]

Similar harsh remarks can be heard or actions (like summoning editorial staff to a meeting) happened in the next few years. And after struggle and conformity, the board of the Straits Times decided that they would "give priority to informing a more serious vein and from a Singaporean point of view, stressing opinions which support national aims, but avoiding becoming a mouthpiece for the government."[10] Although whether in practice they can really achieve that aim, it did reveal to us a true picture of press control in Singapore and the struggle and conformity of a newspaper that was originally guided by western journalistic concepts.

Another important aspect of Singapore media is the various laws and policy that are imposed on media to maintain internal racial harmony and political control. Actually, media control and selfcensorship are important factors that enabled the ruling parties (PAP in Singapore) to stay in power. [11]As Birch puts,

This is a legitimating strategy for keeping the PAP in power: it requires a compliant media to stage the myths, generated by government, in order to manipulate and control social consciousness. All societies and cultures do this to some extent. What makes Singapore different from most is that it admits to what it is doing, and legitimates it within a postcolonial discourse of nation-building. [12]

The major media laws that regulate the Singapore newspapers are as follows:

- Newspapers and Printing Presses Act (1974, 1977,1986,1988,1990,2003)

- Internal Security Act $(1960,1963,1997)$

- Public Entertainment Act(1959)

- $\quad$ Sedition Act (1964)

- Emergency(Essential Power) Act (1964)

- Official Secret Act(OSA)

- Defamation Laws(1957,1997)

- Undesirable Publications Act (1967)

- Essential Control of Publication and Safeguarding of Information Regulation(1970)

- The Emergency(Essential Powers)Act (1964)

- Under so many laws and regulations, local journalists or editors have become "aware of the 'OB' (out-of-bounds) markers' and choose to exercise self-censorship, believing in the 'better safe than sorry' principle." [13] The general public also feels the tight media control by government and hence tends to view "the news coverage is always consistent with the interest of the government [14]".

It is worth noting that in the early 1970s the print media was attacked by the government and actions like cutting circulation or complete demise of the publication were imposed. The editor of Malay-language Utusan Melayu was imprisoned for 15 years while four senior members of Nanyang Siang Pau, was accused of "stirring up racial issues and glamorizing communism"; the two English newspapers Eastern Sun and Singapore Herald were closed down for "convert subversion"[15]. Even foreign media like Newsweek, Time, the Asian Wall Street, and others were either sued for defamation or have their circulation cut dramatically if their reports did not follow the rules.

- In a word, the "tremendous privilege, to scope and define the message (and messages)" from the government, enacted through various laws and policies and keep amending them since the 1960s, to cater to the changing situation, is one of the "hallmarks of the media and cultural management" of Singapore.[16] 
I. Among the tasks that top the leadership's concern is the national-building. From the early days when Singapore gained its independence and became a republic, the leaders have been aware of the challenges its multiracial and multireligious society posed. Although it is a country with $76 \%$ being ethnic Chinese, it is surrounded by Malaysia and Indonesia with a suspicion whether it would become a "third China" in Southeast Asia. Therefore issues and problems that are related to race and procommunist opinions or activities are considered sensitive and should be handled carefully. Since communication can be used to "bring about national cohesion" or to "widen social cleavages" [17], in Singapore, the media have been turned into 'depoliticized' entities [18]. It has become the one whose main function is to "inform, educate and entertain Singaporeans for the purpose of communitarian national building", and to "stay away from sensitive political issues" [19]. And the media strategies and policies are described by scholars as "measured ideological framework of a domestic and regional postcolonial politics of nation-building" [20]. Relevant research done on "Straits Times and the national building" has confirmed that the Straits Times reflects the" top-down approach" of the government. It works "in support of the government and the nation-building efforts" [21]. Survey and Indication

In a country where the press is under strict control, it's common to see criticism of the reliability of the newspapers as being the mouthpiece of the government. Despite the harsh words, people in Singapore would still turn to the newspaper for important news.

In a survey on "mass media and communication patterns in Singapore", done by Chen \& Kuo in 1977, newspapers were rated by $51 \%$ of the 612 respondents as the most useful sources for various types of information, greatly surpassing other media types (television $22.9 \%$, magazine $7.9 \%$ and movie $3.1 \%$ ). And newspapers were the most useful for almost all type of information, except for entertainment. For information on government policies and public affairs, $67.8 \%$ of the respondents consider newspaper as the most useful source $.48 .8 \%$ of the respondents claimed that newspapers were the most reliable of all the mass media. . For information on government policies and public affairs, $61.1 \%$ indicated that newspapers were the most reliable source. Taking into account that this survey was done in 1977 when there were only few media types to choose from and the internet came far years later, not to mention the influence of the new media, it is no wonder we get this seemingly contradictory result. When people have fewer choices and fewer ways to get connected to the outside world, as compared with situation today, newspaper can play a much significant role in shaping people's ideology and perception of the outsider world. Nevertheless, with fewer influential factors outside, the perception imposed by the government through the media would be more easily accepted and formed by the public.

All these finding greatly contradict our former prediction of a suspicious attitude towards media. Yet it should also be bear in mind that in the 1970s when the technologies were still in the prime stage, information flow still had a long way to go.

\section{Conclusions}

The 1970s is an important stage in the development of Singapore's English press. It reshaped the picture of the Singapore's media circle and forced the English press abandon the past dream of becoming the fourth estate of the nation, and began to take a more positive part in the nation-building process.

In an era (1970s) when most of the information came from press, radio and TV, people would be affected more by this communication strategy, in contrast to situation in new century when internet and mobile phone bring us more options and more suspicions. Therefore, a further research would be needed to incorporate the whole social landscape into the media studies in the future.

\section{Acknowledgment}

This paper is supported by the Fundamental Research Grant for the Central Universities of China, at the Xiamen University, Xiamen, China. The Grant No is 0650-ZK1055. 


\section{References}

[1] S,H. Bi, "The Concise History of Singapore",Guzhou:World Book Publishing House Gazhou Company Ltd.,2012,p39.

[2] Saw Swee-Hock, "The Population of Singapore",Singapore: Institute of Southeast Asian Studies,2007,p47.

[3] Lent, John A. ,"Newspaper in Asia”, Hong Kong: Heinemann Asia: 1982 : Page284.

[4] Kuo, E.C.Y. "The Singapore Press and Asian Values: Some Sociological Observations". Paper presented to the seminar on "The Social Role of Singapore Newspapers in Promoting Asian Cultures and Values", 20 Dec. 1990. Singapore: Singapore Press Holdings. .

[5] Durham, M.G. \& Kellner, D.M., "Media and Cultural Studies Keyworks", Oxford: Blackwell Publishing, 1991:page IV.

[6] Kuo, Eddie C.Y., "Communication policy and national development". In AMIC Seminar on Media Laws and Regulations in Asia:Singapore, Jan 7-8,1986. Singapore:Asian Mass Communication Research\& Information Center.

[7] The Mirror, 14 June 1971. Cited in Kuo, Eddie C.Y., "Communication policy and national development". In AMIC Seminar on Media Laws and Regulations in Asia: Singapore, Jan 7-8, 1986. Singapore:Asian Mass Communication Research \& Information Center.

[8] Turnbull, C.M., "Dateline Singapore: 150 years of the Straits Times", Singapore: Singapore Press Holding, 1995:p 316.

[9] Ibid:p316.

[10] Ibid:p318.

[11]Kaur, K. \& Ramanathan S. “ 'Wither' media regulations?”, Journal of International Communication,2008,p14:1,7-27.

[12]Birch, D., "Singapore Media: Communication strategies and practices", Melbourne: Longman Cheshire,1993. Cited in Lee, T. \& Willnat, Lars. "Media Research and Political Communication in Singapore", working paper of Asia Research Center of Murdoch University of Australia, 2006, No 130.

[13]Cenite, M. "Singapore: Too much legislation, too little expression", in K Seneviratne \& S. Singarayar (eds) Asia's March Towards Freedom of Expression, Singapore, AMIC, 2006,p16798.

[14]Kuo, E. C. Y., Holaday D., \&Peck E. " Mirror on the wall: Media in a Singapore Election. Singapore: AMIC,1993; Hao, X.M., "The press and public trust: the case or Singapore". Asian Journal of Communication, 6(1),1996 pp 111-123. Cited in "Judgment- heuristic or attitudeinfluenced? Explaining perception of news bias in a regulated press system”. (Author unknown), conference paper of International Communication Association.

[15] Chee, Soon Juan, "Pressing for Openness in Singapore", Journal of Democracy, Volume 12, Number 2,2001: p164.

[16]Lee, T. "The Media, Cultural Control and Government in Singapore”, Oxon: Rouledge,2010: p15.

[17]UNESO , "Dynamics of Nation Building with Particular Reference to the Role of Communication", Asia Pacific Institute for Broadcasting Development, Bangkok, 1980. Cited in Birch, D., Singapore Media: Communication Strategies and Practices, Melbourne: Longman Cheshire, 1993:p 65. 
[18] Mauzy, D.K., \& Miline, R.S. "Singapore Politics under the People's Action Party", London and New York: Routledge,2002.

[19]Birch, D.,"Singapore Media: Communication Strategies and Practices", Melbourne: Longman Cheshire,1993. Tan, T.H., "Virtual coffee shop talk, or a force to be reckoned with?", The Straits Times, October 15,2003:15.Cited in Lee, T. \& Willnat, Lars. "Media Research and Political Communication in Singapore", working paper of Murdoch University of Australia, 2006,No 130.

[20]Birch, D., "Singapore Media: Communication Strategies and Practices”, Melbourne: Longman Cheshire: 1993:vii.

[21] Soon, H.L.M, "The Evolution and Practice of development Journalism in the Straits Times”, BA Dissertation

of National

University

of

Singapore,

1994. 